\title{
Recruitment of Educators: Efforts to Improve the Quality of Education in MTS Negeri 2 Medan
}

\author{
Muhammad Fuad Zaini ${ }^{1}$, Oda Kinata Banurea², Mansur Hidayat Pasaribu ${ }^{3}$ \\ 1 Universitas Islam Negeri Sumatera Utara, Indonesia \\ 2 STIT Labuhanbatu Utara, Indonesia \\ 3Universitas Islam Negeri Sumatera Utara, Indonesia \\ fuadzaini06@gmail.com,mansyurhidayatpasaribu@gmail.com,odzawae@gmail.com
}

\begin{abstract}
Abstrac
This study examines how the recruitment management pattern was carried out by Madrasahs at MTs Negeri 2 as an effort to improve the quality of education, how recruitment is in its implementation, and whether there are obstacles during implementation and the solutions offered by madrasah management. The research method used is descriptive qualitative with a case study technique. The results of the study include the recruitment process which includes the socialization of the announcement of the admission of new educators, administrative selection, written tests, Madrasah interview tests, and school tests (microteaching, school interviews, computer tests, and Al-Qur'an reading and writing tests) carried out accordingly. procedures prepared by the Recruitment Team. Recruitment is carried out following the implementation procedure by prioritizing the main objective of selecting the most qualified educators according to the standards set by MTs Negeri 2 Medan. Supervision of the Recruitment Team carried out by Madrasahs and Heads of MTs Negeri 2 Medan to avoid the possibility of misappropriation or deviation from the Recruitment Team. Meanwhile, for the supervision and evaluation of new educators obtained from the recruitment selection results, they are given time for internships. Internships are carried out to evaluate new educators, see efforts to improve themselves, and see innovations made even to evaluate moral behavior and work behavior during the internship.
\end{abstract}

Key Word : Recruitment, Moral, Implementation, Al-Qur'an

\section{Introduction}

National education aims to educate the nation's life and develop human beings as a whole, namely people who believe and fear God Almighty and have high character, knowledge and skills, physical and spiritual health, a solid and independent personality, and a sense of social and national responsibility.

Quality improvement can be done by striving to make schools effective, good leadership and ability to adapt to Zama changes, leaders able to face challenges, quality teacher performance, organizational culture and climate, the participation of stakeholders,(Fadhli, 2017, Banure, 2019).

Recruitment is carried out in an organization because of the possibility of vacancies for various reasons including The establishment of a new organization, the expansion of organizational activities; the creation of new jobs and activities; there are workers who move to other organizations; there are 
workers who quit, either with respect or disrespect; there are workers who quit due to entering retirement age; and the workers who died (Danang Sunyoto, 2012).

(A'yun et al., 2019) the implementation of teacher recruitment aims to get professional and qualified educators. Before conducting recruitment activities, careful preparation and processes are required. The preparation and recruitment of these educators must be mature so that through this recruitment schools can get professional educators according to school criteria because it will have an impact on student output.

The effective forms of recruitment according to Stoner (Hasibuan, 2009) are as follows;

a. Determine and categorize short and long-term HR needs

b. Always pay attention to changing conditions in the labor market

C. Developing the most suitable recruitment (promotion) media to attract applicants

d. Storing data on the number and quality of job applicants from each source and following up on each application for job applicants to then evaluate the effectiveness of the recruitment efforts that have been made

Research results (Rony, 2018) There are several stages in the teacher recruitment system, namely preparation for recruitment, dissemination of announcements, acceptance of applications and new teacher selection. While the obstacles that occur in the teacher recruitment system are the habits of job seekers, external environmental conditions and organizational factors, including internal policies, reward policies, policies regarding employment status and human resource plans. (Sandela, 2019) Recruitment of educators can also be carried out by disseminating announcements, receiving applications, selecting educators, and making educator recruitment decisions. And do good supervision. Quality improvement is also student-oriented, for that recruitment must be accompanied by an analysis of the teacher's ability to formulate learning, looking at educator behavior(Zaini, 2019).

Teacher competence is learning agents at the primary and secondary education levels as well as early childhood education. (Riyanto, 2010) in Permendiknas Number 16 of 2007 Article 1 which states that "teachers must meet the academic qualification standards and teacher competencies that apply nationally", namely the academic qualifications of teachers at SD / Ml, or other equivalent forms, must have academic qualifications. Minimum education diploma four (D-IV) or undergraduate (S1) in the field of SD / Ml education (D-IV / S1-PGSD / PGMI) or psychology obtained from an accredited study program. As someone who plays an important role in the process of advancing the quality of education, educators must have the competence to support their main performance. Based on Permendiknas No. 16 of 2007, teachers must have 4 competencies, among others: Pedagogic Competence, Expertise Competence, Social Competence and Professional Competence. Pedagogic competencies, which must be possessed by an educator in this competency include: Mastering the characteristics of students from 
Recruitment of Educators: Efforts to Improve the Quality of Education in MTS Negeri 2 Medan

physical, moral, social, cultural, emotional, and intellectual aspects; master learning theory and teaching-learning principles; developing a curriculum related to the subjects being taught; organize educational learning; make use of Computer Science Engineering (ICT) for the benefit of learning; facilitate the development of the potential of students; communicate effectively, empathically, and politely to students; as well as conducting an assessment of the evaluation of learning processes and outcomes (Abdurrahman, 2009).

Competency skills, competencies that must be possessed by educators, in this case, include: Acting under religious, legal, social and cultural norms of the nation; honest appearance, noble character, the role model for students and society; presents himself as a person who is stable, stable, mature, wise and dignified; and shows a work ethic, high responsibility, a sense of pride in being a teacher, and self-confidence; upholding the code of ethics for the teaching profession (Bafadal, 2008). MTs Negeri 2 Medan is the one whose existence is very much in demand by the community because it is one of the high-quality educational institutions. This can be seen from the teachers and students owned by the Madrasah, where MTs Negeri 2 Medan is designed as a future-oriented flagship to create a generation with Islamic character by adhering to Faith and Taqwa (IMTAQ) and to equip their students as provisions for their future life. to face future challenges with Science and Technology (IPTEK). MTs Negeri 2 Medan is designed to carry out educational development with certain characteristics of excellence under Islamic values, peculiarities of economic potential, and regional culture. For this reason, MTs Negeri 2 Medan is trying to prepare a generation capable of fighting for Islamic values during the receding times of aqidah and faith. MTs Negeri 2 Medan already has a good image in the eyes of the community. This can be proven by the many achievements that have been made by MTs Negeri 2 Medan. To maintain that image, the quality of learning at MTs Negeri 2 Medan must be maintained and even improved. Because teachers are the spearhead of the delivery of education at MTs Negeri 2 Medan, recruitment is one way to find qualified educational personnel.

MTs Negeri 2 Medan is known as students who are smart, independent, and equipped with good memorization. But behind all that, the teaching staff at the Madrasah certainly plays a very important role in producing the output of students who are so well known to the public. Improving the quality of education starts with new educators and then can produce students according to the expectations and goals of their educational institutions. After many achievements at the regional level, MTs Negeri 2 Medan is increasingly in demand by the community. From year to year, more and more people are registering their children at MTs Negeri 2 Medan. However, with the conditions and the number of rooms owned by MTs Negeri 2 Medan, the number of students accepted is limited according to their needs. From this, MTs Negeri 2 Medan strives to always improve the quality of education. One of the efforts that have been made is through the recruitment of educators. The recruitment carried out by 
MTs Negeri 2 Medan is aimed at producing quality human resources, as part of improving the quality of education for their students, and of course, the recruitment carried out must be following the needs of the Madrasah, and the requirements set by the Madrasah, so that recruitment is not only carried out just filling the vacancies for employees but getting dedicated and professional human resources in their fields to improve the quality of Madrasah education. In this study, we will see how the Recruitment of Educators: Efforts to Improve the Quality of Education in MTS Negeri 2 Medan

\section{Research methods}

The research method used is to use a qualitative approach, which is a type of research in which the procedure of discovery does not use statistical or quantification procedures. In this case, qualitative research is research about a person's life, stories, behavior, and also about organizational functions, social movements, or reciprocal relationships. back. (Nasution, 1982) The research method used in this research is the case study method. A case study (Case Study) is a study conducted in an incentive, detailed and in-depth manner towards an organization, institution, or specific phenomenon. case study (Case Study) is a form of research that can be carried out on an individual, group of individuals, human groups (teachers, ethnic groups), human-environment (villages), or social institutions. This research was conducted to understand and provide an overview of the data contained in the Evaluation of the Environmentally Friendly Madrasah Program in MTs Negeri 2.

\section{Result and Discussion}

Management of teaching staff recruitment as part of improving the quality of education at MTs Negeri 2 Medan. The recruitment of teaching staff at MTs Negeri 2 Medan is an innovation in an educational institution. For the recruitment of teaching staff, the management body at MTs Negeri 2 Medan provides consideration and approval according to the recruitment mechanism. Research on Teacher Recruitment Management in Improving the Quality of Education at MTs Negeri 2 Medan can be grouped into four stages, namely 1). planning, organizing, actuating, and controlling.

a) Planning

Through the initial analysis carried out by the head of a madrasah, for the continuity of education and the real need for teaching staff, the head of the madrasah sees the need for new educators. As part of the initial planning for the recruitment of educators at MTs Negeri 2 Medan, the parties at MTs Negeri 2 Medan formed a committee for recruiting educators. Then the committee for admitting teaching staff or the assigned team is called the Recruitment Team. Furthermore, this Recruitment Team is responsible for a whole in the recruitment process. The recruitment of new teaching staff is fully carried out by a special team or committee formed by the school and endorsed. This is done to facilitate work programs in the recruitment process for new educators. 


\section{Recruitment of Educators: Efforts to Improve the Quality of Education in MTS Negeri 2 Medan}

In the recruitment of teaching staff at MTs Negeri 2 Medan, the committee for recruiting did not have a routine recruitment schedule. The recruitment of teaching staff is carried out only if MTs Negeri 2 Medan feels the need to add new teaching staff. Because recruitment was only carried out when MTs Negeri 2 Medan had a shortage of educators, there was no annual routine schedule. The recruitment of new teaching staff is carried out by sharing considerations, for example, some educators are not active (retire, or move from school), or because of the need for teachers that do not yet have at MTs Negeri 2 Medan to teach certain subjects.

Preparation for the recruitment of new teaching staff at MTs Negeri 2 Medan which was carried out by the Recruitment Team was to follow up on complaints from the school that was reported by the head of the madrasah using field observations related to the report. After it is assessed that recruitment needs to be held, then the Recruitment Team will determine the requirements for applicants for new educators/teachers.

Furthermore, the Recruitment Team prepares a recruitment strategy, makes a recruitment schedule, and distributes announcements for the recruitment of new educators (announcement of job vacancies). The announcement of job vacancies is carried out in various ways such as disseminating information through teachers, through the school website, and advertisements in Solopos newspapers. The newspapers and websites contain information on the formation needed and the conditions that must be prepared by the applicant, which includes the number of formations required, the requirements that must be met by the applicant, the time and place for the recruitment.

b) Organizing (Pengorganisasian)

The recruitment team that was formed then determined people to be the supervisory team, the testing team, the team that helped recruitment administration, whose membership consisted of the head of the madrasah, and teachers at MTs Negeri 2 Medan.

c) Actuating (Penggerakkan)

the selection is also carried out for every applicant who enters and is checked carefully. Each applicant who passes administration, the committee will inform prospective new educators to take the next test, namely by conducting a screening process carried out by the Recruitment Team in recruiting new educators at MTs Negeri 2 Medan, namely through the stages that have been determined by the Recruitment Team, up to the decision making at the plenary session that applicants pass to become new teaching staff at MTs Negeri 2 Medan. Requirements for prospective educators are not only from the Recruitment Team but also have special requirements that new prospective educators must-have.

The recruitment of new teaching staff by the Recruitment Team is already good, where the recruitment of new teaching personnel begins with a report on the shortage of new teaching staff reported by the school for the recruitment of new teaching staff. 


\section{Recruitment of Educators: Efforts to Improve the Quality of Education in MTS Negeri 2 Medan}

In the process of recruiting new teaching staff at MTs Negeri 2 Medan, it involved the head of the madrasah and teachers at MTs Negeri 2 Medan. Because those who know exactly what the needs in the working area are the head of the madrasah and teachers, the ones who can determine the standards and who are appropriate are the head of the madrasah and the teachers.

The decision making from the recruitment of new educators was carried out through a plenary session of determining the applicants who were selected to become new educators at Mts Negeri 2 Medan, the Recruitment Team involved the principal of the madrasah which in determining the values obtained by the applicant were considered. The results of the scores are not solely for consideration but also take into account the applicants' achievements, work experience, and other documents that support the competence of prospective educators which are included in the application file.

The obstacles faced in recruitment by the Recruitment Team in carrying out their duties are not many, it's just that when one of the applicants has a relative relationship with one of the senior teachers, the school and there is an "order" of relatives to be passed it becomes a mental burden for the Recruitment Team to remain fair and transparent. However, this is not a significant problem because the solution can be seen from the series of tests it has passed and the scores obtained during the selection.

\section{d) Controlling}

The principal of the madrasah plays a role in supervision which is fully directed to avoid the possibility of diversion or storage of the goals to be achieved. Through supervision, it is hoped that it can help implement the policies that have been set to achieve the planned goals effectively and efficiently. The school strives to improve the quality of education at MTs Negeri 2 Medan as for the strategy taken, namely through coaching, namely coaching in general and coaching specifically, carried out by schools and schools. This is done to always maintain quality, improve, and develop the potential of educators.

The method used by schools in improving the quality of teaching staff is the apprenticeship. Internships are carried out after being declared accepted as new educators. The new educators have to do an apprenticeship first before actually teaching in their respective sections, for example, the prospective grade 1 teacher teaching grade 1, the father explained that this internship is carried out 3 to 4 months before the new school year, because recruitment is also carried out around 3 to 4 months, they will begin to join classes that they will later teach, during the apprenticeship period there will be coaching carried out by the head of the madrasah, PUK Curriculum, PUK Ketenagakerjaan. The core of the coaching is about institutions, how to teach, and how to serve the community This activity is carried out during empty hours, sometimes it is carried out according to children's lesson hours, the 
implementation time is conditional because the time also adjusts to the free hours, and the schedule for the material.

Efforts to improve the quality of educators at MTs Negeri 2 Medan are inseparable from improving the quality of education, intending to always improve the quality of students embodied by student achievement.

As for the coaching carried out at MTs Negeri 2 Medan for new or old educators. According to Mr. Slamet, there are several things that the school has done to strengthen or develop the abilities that are already possessed by selected educators, namely in 2 (two) ways, namely in general and specifically. In general, it takes 2 (two) stages.

First, improving the quality of schools, this is so that all teaching staff has the same standard, the standard set by MTs Negeri 2 Medan. Example: In terms of ethics, dress/uniform, manners, discipline in work, general insight, and other social norms. This activity is held individually by MTs Negeri 2 Medan and is held intensively on Sundays. Second, improving the quality of schools. This is so that all staff and employees at MTs Negeri 2 Medan can meet with the school. This activity contains, among others: general information by the school, school evaluation of schools, religious studies, and new policies from the school. This activity is carried out every two weeks after each subject, on a predetermined day

Furthermore, in particular quality improvement, this activity contains matters relating to subjects. This activity is carried out 1 (one) time a week during the tahfid and tahsin subjects. Tahfid and tahsin lessons are held once a week at the same time starting from grades 1-3. It is intended to discuss all classroom teacher problems such as equating teaching standards and methods, knowledge of teaching materials, making teaching materials, and making teaching devices. All class teachers are collected according to class then one of them who is superior and capable in certain subject matter provides this knowledge so that all class teachers have the same competence in teaching. If all classroom teachers cannot explain the knowledge in a particular lesson, the head of the madrasah will bring in outside speakers.

1. Barriers during the recruitment process

The implementation of the overall management of the recruitment of new educators at MTs Negeri 2 Medan will certainly have obstacles and obstacles. However, the obstacles experienced are not a serious problem for its implementation, because the Recruitment Team has prepared everything carefully. It has even prepared a solution that will be carried out if there are obstacles and obstacles because the Recruitment Team is always learning and evaluating every recruitment period, from time to time there are always improvements. There is only one obstacle in the management of teaching staff recruitment in improving the quality of 
Recruitment of Educators: Efforts to Improve the Quality of Education in MTS Negeri 2 Medan

education at MTs Negeri 2 Medan, namely the mental burden when there is pressure/requests/orders from certain parties to let their relatives/relatives pass during the recruitment process.

2. Solution done

MTs Negeri 2 Medan adheres to always improving quality. All recruitment processes are aimed at improving the quality of education at MTs Negeri 2 Medan. Thus, the obstacles that exist during the recruitment process such as requests/pressure from senior teachers, schools, or any party to accept/pass their siblings during the recruitment test do not become meaningful if the coordination of all people related to recruitment goes according to procedures. This means that all processes are carried out according to the rules and plans, so pressure from any party will not be able to change the result. Because the selection test during the recruitment process was done by the participants themselves, there were no jockeys (substitute people) and the supervisors and examiners performed their duties as an obligation to always improve the quality of education at MTs Negeri 2 Medan. If you only include relatives/relatives without expertise that match the criteria of MTs Negeri 2 Medan then it will embarrass the name of "the bearer". So by having to pass the selection test naturally and according to the procedure, this will ward off any constraints (demand/pressure) from any party.

\section{Conclusion}

The recruitment of new teaching staff at MTs Negeri 2 Medan has been carried out well. A good support system is a major component in the recruitment of new teaching staff at MTs Negeri 2 Medan so that it can produce good and quality educators. Based on data analysis from research conducted by focusing on the management of new teaching staff recruitment at MTs Negeri 2 Medan that has been described. The recruitment implementation process which includes the socialization of the announcement of the admission of new educators, administrative selection, written tests, Madrasah interview tests, and school tests (microteaching, school interviews, computer tests, and Al-Qur'an reading and writing tests) are carried out according to the procedures prepared. by the Recruitment Team. Recruitment is carried out following the implementation procedure by prioritizing the main objective of selecting the most qualified educators according to the standards set by MTs Negeri 2 Medan. Supervision of the Recruitment Team carried out by Madrasahs and Heads of MTs Negeri 2 Medan to avoid the possibility of misappropriation or deviation from the Recruitment Team. Meanwhile, for the supervision and evaluation of new educators obtained from the recruitment selection results, they are given time for internships. Internships are carried out to evaluate new educators, see efforts to improve themselves, and see innovations made even to evaluate moral behavior and work behavior during the internship. 


\section{References}

A'yun, Q., Imron, A., \& Arifin, I. (2019). Rekrutmen Tenaga Pendidik Di Sma. Jurnal Pendidikan: Teori, Penelitian, \& Pengembangan, 4(7). https://doi.org/http://dx.doi.org/10.17977/jptpp.v4i7.12613

Abdurrahman, M. (2009). Pendidikan Bagi Anak Berkesulitan Belajar. Rineka Cipta.

Bafadal, I. (2008). Peningkatan Profesionalisme Guru Sekolah Dasar. Bumi Aksara.

Banure, O. K. (2019). Pendidikan, Peran Kepempimpinan Kepala Sekolah Dalam Manajemen Perubahan Di Lembaga. Benchmarking-Jurnal Manajemen Pendidikan Islam, 3(1), 1-18. https://scholar.google.com/citations?user=jocgVosAAAAJ\&hl=en\#d=gs_md_citad\&u=\%2Fcitations\%3Fview_op\%3Dview_citation\%26hl\%3Den\%26user\%3DjocgVosAAAAJ\%26ci tation_for_view\%3DjocgVosAAAAJ\%3Ad1gkVwhDpl0C\%26tzom\%3D-420

Danang Sunyoto. (2012). Manajemen Sumber Daya Manusia. CAPS (Center for Academic Publishing Service).

Fadhli, M. (2017). Manajemen Peningkatan Mutu Pendidikan. Tadbir: Jurnal Studi Manajemen Pendidikan, 1(2), 215. https://doi.org/10.29240/jsmp.v1i2.295

Hasibuan. (2009). Manajemen Sumber Daya Manusia. Gramedia.

Nasution, S. (1982). Metode research. Jemmars.

Riyanto, Y. (2010). Paradigma Baru Pembelajaran (Sebagai Referensi bagi Pendidik dalam Implementasi Pembelajaran yang Efektif dan Berkualitas. Kencana.

Rony, R. (2018). Sistem Rekrutmen Tenaga Pendidik (Guru). Jurnal Studi Islam Miyah, 2(14). https://ejournal.inkafa.ac.id/index.php/miyah/article/view/147

Sandela, M. (2019). Manajemen Rekrutmen Tenaga Pendidik Di Sdit Sa'adiah Kecamatan Kubung Kabupaten Solok. Al-Fikrah: Jurnal Manajemen Pendidikan, 7(2), 155. https://doi.org/10.31958/jaf.v7i2.1674

Zaini, M. F. (2019). The Implementation Of Learning Management In Class Viii Madrasa Tsanawiyah Islamiyah (Mts) Ypi Batangkuis. International Conference on Islamic Educational Management (ICIEM). https://scholar.google.co.id/citations?user=9xE516oAAAAJ\&hl=id\#d=gs_md_cita$\mathrm{d} \& u=\% 2 F$ citations \%3Fview_op\%3Dview_citation\%26hl\%3Did\%26user\%3D9xE516oAAAAJ\%26ci tation_for_view\%3D9xE516oAAAAJ\%3Au5HHmVD_uO8C\%26tzom\%3D-420 
Recruitment of Educators: Efforts to Improve the Quality of Education in MTS Negeri 2 Medan 